City University of New York (CUNY)

CUNY Academic Works

2010

\title{
From Ideal to Practice and Back Again: Beginning Teachers Teaching for Social Justice
}

Ruchi Agarwal

University of California, Santa Cruz

Shira Epstein

CUNY City College

Rachel Oppenheim

Teachers College

Celia Oyler

Teachers College

Debbie Sonu

CUNY Hunter College

\section{How does access to this work benefit you? Let us know!}

More information about this work at: https://academicworks.cuny.edu/hc_pubs/277

Discover additional works at: https://academicworks.cuny.edu

This work is made publicly available by the City University of New York (CUNY).

Contact: AcademicWorks@cuny.edu 


\title{
From Ideal to Practice and Back Again: Beginning Teachers Teaching for Social Justice
}

Journal of Teacher Education $X X(X)|-| 1$

(C) 2010 American Association of Colleges for Teacher Education Reprints and permission: http://www. sagepub.com/journalsPermissions.nav DOI: | $0 . \mid$ | 777/0022487|0935452 | http://jte.sagepub.com

(S)AGE

\author{
Ruchi Agarwal, ${ }^{2}$ Shira Epstein, ${ }^{3}$ Rachel Oppenheim, ${ }^{1}$ \\ Celia Oyler, ${ }^{4}$ and Debbie Sonu ${ }^{5}$
}

\begin{abstract}
The five authors of this article designed a multicase study to follow recent graduates of an elementary preservice teacher education program into their beginning teaching placements and explore the ways in which they enacted social justice curricula. The authors highlight the stories of three beginning teachers, honoring the plurality of their conceptions of social justice teaching and the resiliency they exhibited in translating social justice ideals into viable pedagogy. They also discuss the struggles the teachers faced when enacting social justice curricula and the tenuous connection they perceived between their conceptions and their practices. The authors emphasize that such struggles are inevitable and end the article with recommendations for ways in which teacher educators can prepare beginning teachers for the uncertain journey of teaching for social justice.
\end{abstract}

\section{Keywords}

social justice, teacher education, teacher reflection, curriculum development

\section{Introduction}

Many teacher education programs across the United States express commitments to social justice and accordingly attract prospective teachers who seek to work for social change. These social justice commitments are certainly broad and diffuse but stem in no small part from the structural inequalities in our society that are reflected in-and perpetuated by-our schools. We know, for instance, that students in low-income communities are more likely to receive fewer resources and a qualitatively substandard education compared to their middle-class counterparts (Ferguson, 2000; Kozol, 1991; Rothstein, 2004). So too, students of color are often denied adequate educational resources, are overrepresented within special education contexts, and are subject to harsher forms of punishment than their White peers (Losen \& Orfield, 2002; Mukherjee, 2007; Oakes, Wells, Jones, \& Datnow, 1997). Of course, these are not new trends, as U.S. schools have historically failed to adequately serve students outside the White, English-speaking, middle-class, nondisabled, mainstream culture (Zollers, Albert, \& Cochran-Smith, 2000). To combat such inequalities, social justice is emphasized as an integral part of many teacher education curricula.

When seeking to transform inequities inherent in society and expressed so sharply in schools, classroom teachers can be understood as "the most essential element [as] they have the ultimate responsibility to navigate the curriculum and instruction with their students" (Lalas, 2007, p. 19). Consequently, we, as teacher educators, feel the charge of this responsibility, both in our university-based curriculum design and in our research on the consequences of our justice-oriented teacher education with preservice teachers. To that end, we developed a multicase study of recent graduates of our elementary preservice program. We explored with these beginning teachers their classroom enactments of social justice-oriented curriculum to investigate ways that our university curricula might better prepare teachers for the realities of teaching for social justice within our current public school system. This article discusses our graduates' conceptions of teaching for social justice, their curricular enactments, and their reflections. Although we were insistent that our classroom-based data collection with beginning teachers be respectful and nonevaluative, we use our findings to highlight and critically analyze some of the important possibilities and challenges we face in our teacher education work when preparing teachers to advocate for social change through their pedagogy. Our work was inspired by our understanding that a commitment to social

\footnotetext{
'Teachers College, New York

${ }^{2}$ University of California, Santa Cruz

${ }^{3}$ City College of New York

${ }^{4}$ Teachers College, New York

${ }^{5}$ City University of New York

Corresponding Author:

Rachel Oppenheim, Teachers College, Columbia University-Curriculum \& Teaching, 525 W. I 20th St., New York, NY 10027

Email:rlo2101@columbia.edu
} 
justice teacher education must be partnered with a commitment to self-study and self-reflection. Thus, this work is born from a position of self-criticism and critique that undergirds various social movements (Hale, 1991).

We begin the article by framing our work in relation to the literature on beginning teachers and teaching for social justice. Next, we describe our method of study. This is followed by three cases, each of which highlights a different beginning teacher and her conceptions and enactments of social justice education. The cases illustrate some of the difficulties beginning teachers face when seeking to enact social justice curricula and teach in a way that reflects their ideals. In spite of these struggles, these cases also reveal the potential that many new teachers have to teach toward justice curricula, even as they doubt their own ability to do so. We conclude with a set of recommendations for ourselves and other teacher educators who are dedicated to supporting new teachers in creating socially just curricula.

\section{Framing and Researching Social Justice Teacher Education}

The phrase social justice has proliferated in teacher education in recent years and is an umbrella term encompassing a large range of practices and perspectives (Adams, Bell, \& Griffin, 2006). These highlight the importance of multiple concepts, including but not limited to building classroom communities of dialogue across and with difference (SaponShevin, 1999), critical multicultural and antibias education (Derman-Sparks \& Ramsey, 2006; Schniedewind \& Davidson, 2006; Sleeter, 2005), culturally relevant pedagogy (Ladson-Billings, 1994), culturally responsive and competent teachers (Irvine, 2003), antiracist teaching (Berlak \& Moyenda, 2001), equity pedagogy (Banks \& Banks, 1995), anti-oppressive teacher education (Kumashiro, 2004), disability rights (Linton, 1998), ableism (Hehir, 2002), and access to academics for students with disabilities (Kluth, Straut, \& Biklen, 2003). There is an increasing number of books that are designed specifically for social justice-oriented teacher education building on the missions of teaching for social change (Darling-Hammond, French, \& Garcia-Lopez, 2002; Oakes \& Lipton, 2007), teaching and learning in a diverse world (Nieto, 2005; Ramsey, 2004), and critical, social justice teacher education (Cochran-Smith, 2004; Sleeter, 2005; Soohoo, 2006; Wade, 2007).

Clearly, the idea of teaching for social justice can be related to a range of different practices and values. Although the openness of this term offers teachers many entry points into the endeavor of social justice teaching, it also poses problems for teachers and teacher educators. Teachers can feel overwhelmed by the expectation that they must undo a long list of discriminatory social structures if they are to fully teach for social justice. Teaching for social justice can be seen as an unattainable idea, not linked to particular classroom-based practices. Or because it is an umbrella term, any teacher may be able to claim that she is teaching for social justice after enacting certain elements of the above practices. For example, a teacher can explain that she is teaching for social justice if she allows for conversations about current events, noting that she is enacting culturally relevant pedagogy.

Given these problems, we want to be clear about what we see as the key markers of teaching for social justice. Educators who teach for social justice (a) enact curricula that integrate multiple perspectives, question dominant Western narratives, and are inclusive of the racial, ethnic, and linguistic diversity in North America; (b) support students to develop a critical consciousness of the injustices that characterize our society; and (c) scaffold opportunities for students to be active participants in a democracy, skilled in forms of civic engagement and deliberative discussion. These practices may challenge and alter an educational system that is not adequately serving large numbers of children, particularly poor children, children of color, and children with disabilities.

This vision of social justice teaching reflects an understanding that teachers can work to address and ameliorate systemic inequities with their students. We draw from the knowledge that "individual experience may be shaped by issues of oppression" (McDonald, 2007, p. 2076), placing the lives of students into a sociohistorical educational landscape characterized by trends of inequity. Moving beyond teaching tolerance or appreciating diversity, we want teachers to graduate from our teacher education program with not only knowledge about how racism, sexism, ableism, heterosexism, nationalism, and linguistic privilege operate in schools and society but also the skills for interrogating how these forms of oppression are commonly expressed in school practices and in the curriculum. This perspective assumes that classrooms are too often sites of cultural and social reproduction and that they must be examined carefully for the ways that they produce and perpetuate injustice. Ultimately, we resonate with a social reconstructionist multicultural approach to schooling (Sleeter, 1993). From this approach, teachers work to situate pedagogical practices within analyses of structural inequality and prepare their students to understand injustice on this level.

Teacher educators can emphasize the importance of social reconstructionist approaches to social justice education and assist preservice teachers in enacting related teaching practices in their own classrooms. Our program begins with critical autobiographical analysis, which asks preservice teachers to reflect on their identities and social locations to critique the implicit values, long-held assumptions, and biases that underlie their ways of understanding children, communities, and knowledge (Genor \& Goodwin, 2005). Along with this selfreflection, our teacher education program includes coursework, literature, and assignments designed to explore issues of power, oppression, equity, and social change. Finally, our preservice teachers are asked to design curricula and lesson plans that 
integrate marginalized knowledge, allow for civic participation, and provoke students to question discriminatory social norms. Such teaching is, of course, never neutral, and professors and instructors in the program do not shy away from sharing perspectives with their students, actively disagreeing publicly with each other and also encouraging students to constantly explore the possible effects of their own beliefs on their classroom pedagogy.

Once preservice teachers leave their university programs and enter their own classrooms, their commitments sometimes collide with the realities of being novice teachers in a harrowing and unforgiving school system. Authors reveal a range of dilemmas these novices may confront in their dayto-day practices, describing challenges in areas such as curriculum, lesson planning, assessment, management, time, and school culture (Feiman-Nemser, 2003; Oakes \& Lipton, 2007). The current age of standardization and accountability significantly increases the demands and pressures for teachers in the classroom. Given these obstacles, teaching for social justice can in particular be a daunting and complex endeavor for new educators. To teach for social justice requires one not only to manage the steep learning curve that all new teachers must face but to be able to navigate through a school context laden with hindrances such as instructional pacing, test preparation, and mandated curriculum, many of which work directly against a social justice agenda.

\section{Our Study-Assumptions and Method}

We, the five authors of this article, met in the fall of 2005 to discuss our university's master's preservice elementary inclusive education program (three of us were involved in running that program) and to design a study that would investigate whether and how recent graduates of the program were emphasizing social justice in their curricula. Although we were confident that some beginning teachers graduated from our program with a commitment to social justice, we knew little about how these teachers translated their conceptions and commitments into actual classroom practices. Few researchers have conducted follow-up studies of teacher education graduates to explore how social justice is integrated into instruction and the day-to-day activities of teachers and students in schools. Therefore, we identified such a study as important to pursue.

We launched a multicase study by asking, For beginning teachers who are committed to teaching for social justice, how does this commitment affect their lesson plans and their classroom instruction? We view these lessons and instructional moves as a part of the curricular enactments in their elementary classrooms. Curriculum enactment is defined as not just the delivery of information or adaptation of curriculum but rather as the interactions between and among students and teachers as they interpret and construct meaning through classroom content and pedagogy (Snyder, Bolin, \& Zumwalt,
1992). Rather than viewing curriculum as information that is transmitted from teacher to student, we perceive it as "the educational experiences jointly created by student and teacher" (Snyder et al., 1992, p. 418). This broader conception of curriculum allows us to recognize the ways in which social justice curricula can be regularly enacted, even when they are not part of a premeditated lesson.

We created a weekly research seminar to engage a small group of doctoral students in our research efforts. The five authors of this article were the seminar's teaching team, and 12 students joined us as coresearchers. We knew that within the scope of one semester, we would not be able to complete the study fully and chose to emphasize the processes of data collection and data analysis within the seminar. Therefore, before the semester began, we determined that the study would be centered on multiple cases of beginning teachers and that each doctoral student would learn about the practices of one beginning teacher through observations and interviews.

This research design grew from our assumption of the uniqueness and storied nature of teachers' experiences (Clandinin \& Connelly, 2000). In particular, political understandings are the result of one's life story and social location; therefore, we knew that the teachers would articulate a wide range of personal, evolving, and time-bound beliefs about social justice. We expected that these differences would be exacerbated by the different teaching contexts in which the teachers were working. Although they were mainly in urban settings, the graduates we studied were working in schools with differing levels of racial and socioeconomic diversity, and 1 participant taught in a suburban school. We chose to collect and analyze case studies so that the "local particulars" of each teacher's experiences could be studied (Dyson \& Genishi, 2005, p. 3).

To recruit beginning teachers to participate in the study, we sent an invitation to all graduates of the previous 2 years of our program for whom we had current emails and who were teaching in the geographical area of our teacher education program ( $n=$ approximately 50$)$. We explained in our invitation that we were interested in looking at how beginning teachers who had graduated from our teacher education program enacted social justice curricula in their classrooms. From our perspective, a response to the invitation indicating desire to participate in the study suggested that these teachers had an acknowledged commitment to teach for social justice. Twelve teachers ultimately committed to the study, and each was paired with a graduate student researcher.

Before the doctoral student researchers met the beginning teachers, they engaged with relevant academic readings, including methodological texts and literature related to teaching for social justice within the context of the seminar. The teaching team and the doctoral students also collaboratively developed observation protocols as well as interview protocols. The first interview was designed to help researchers familiarize themselves with their participating teachers and get a 
sense of their backgrounds and their conceptions of social justice. Although the researchers worked with a set of focus questions, the questions were seen as tentative, and as a class, we discussed the importance of keeping our attention on the issues that the participants raised (Glesne \& Peshkin, 1992). Ultimately, the interviews were active, enabling each teacher to refer to personal, and potentially alternative, knowledge and perspectives (Holstein \& Gubrium, 1995). After the interview, each participating teacher identified examples of social justice teaching for the researcher to observe. The researcher then conducted from one to three observations in the teacher's classroom, aiming to collect "unobtrusive data" (Hatch, 1995, p. 214). The observations were followed by informal interviews in which the researcher asked the teacher to describe the lesson and explain how the lesson was an example of social justice teaching. The entire field-based research experience was then concluded with an exit interview in which the teacher explained how her lessons reflected her conceptions of social justice and the hindrances that she experienced when doing this work.

We recognized that by asking teachers to demonstrate specific instances of social justice teaching, we would be narrowing the types of curricular enactments that we would be able to see. In addition, we may have put a binary in place by suggesting that some lessons reflect ideals of social justice and some do not. This does not reflect our belief, and we see the potential drawbacks of this decision. Furthermore, as we explained above, curricular enactments are the interactions and joint experiences between teachers and students (Snyder et al., 1992) and include educational interactions beyond the enactment of classroom-based lessons. That said, each researcher had a limited amount of time in her participant's classroom, and we agreed that asking teachers to identify their own examples of social justice teaching would be the most efficient way to view these enactments in action. In addition, this methodological decision illustrates our dedication to "insider" rather than "outsider" knowledge (Emerson, Fretz, \& Shaw, 1995, p. 30) in that the beginning teachers directed us to particular aspects of their work. We studied the curricular enactments they flagged as reflecting their conceptions of teaching for social justice rather than analyzing lessons based on our conceptions.

The doctoral students and the teaching team engaged in a series of postdata collection activities. First, each of the audio-recorded interviews was transcribed. Second, the doctoral students created lesson plans and narrative vignettes, or storied accounts of the classroom experiences, based on their field notes from the lesson observations. We saw these documents as "interim texts" that are positioned between the field texts and the researched texts (Clandinin \& Connelly, 2000, p. 133). Creating these texts helped us deepen our familiarity with the beginning teachers' experiences. Finally, in the last month of the seminar, we conducted preliminary and rudimentary data analysis across the cases, focused on generating themes through a process of open coding. We identified codes to describe the supports and hindrances the teachers experienced in schools, their personal backgrounds, and their views of justice-oriented pedagogy and content. Some themes of special interest were what we identified at the time as consistencies, contradictions, and uncertainties in the participants' conceptions and enactments of social justice teaching. Many of the participating teachers reported shifts in their views of teaching for social justice as they entered the classroom, and some seemed unclear about how they were teaching for social justice. We shared all data and the emergent codes by posting all documents on the university's class Web system.

From the start of the project, we felt that it was important that our research be of immediate benefit to the research participants. Specifically, we hoped that our participants would gain "self-understanding and, ideally, self-determination," adding to the validity of our study (Lather, 1986, p. 67). Accordingly, at the end of the semester, we organized a dinner for the participants, performed a readers' theater comprising interview quotes, and presented them with a book of vignettes and lesson plans from their teaching. We hoped that this book would help them further develop their knowledge of teaching and ability to teach for social justice.

Although the course officially ended with the semester, we, as the teaching team, systematically dove back into all transcripts and vignettes. We focused on the teachers' varying and evolving conceptions and enactments without comparing them to theoretical frames so as to stay close to their "phenomena of experience" (Clandinin \& Connelly, 2000, p. 128). First, we worked to identify the different conceptions of social justice that the beginning teachers held. Then, we looked to how those conceptions transformed in their classroom experiences and related to the ways that they created and enacted social justice curricula. We continued to read the data in a relatively "open" way, yet we began a process of "selective open coding" (Emerson et al., 1995, p. 155) in which we looked to trace the translation of the teachers' conceptions into practice. We center this finding in this article, discussing the ways their visions shifted in the context of their beginning teaching placements.

\section{The Teachers' Cases}

In this section, we highlight 3 beginning teachers: Lucy, Jane, and Allison. These cases were chosen from the original 12 because of the teachers' clear articulations of the tensions between the ideals of teaching for social justice and classroom practices. Each teacher experienced different struggles when working to enact a curriculum based on her conception of social justice. Also, these 3 teachers worked with different student populations and in varying school settings. Therefore, in spotlighting their work, we illustrate how teaching for social justice can unfold in divergent social locations. Yet despite their varying teaching contexts and struggles to teach for social justice, Lucy, Jane, and Allison all engaged in deliberate attempts to explore social differences and injustices in 
their elementary classrooms. We surface the teachers' conceptions of social justice and the manifestation of their social justice ideals in their practices - in reference to both their own social locations and those of their students. These cases highlight a number of opportunities and struggles that beginning teachers may encounter when translating conceptions into pedagogy.

\section{Lucy}

I want them to realize that it's a hard world out there. Especially because you're deaf. . . . I try not to sugarcoat anything in the class. I let them know about my experiences being Black, and then I let them know that they're going to face the same things because they're deaf. . . I want them to know that they do have rights and everybody should be equal, but —it's not that way. It's not.

When asked to elaborate on her conceptions of social justice, Lucy, a coteacher in an English-American Sign Language bilingual public elementary school, explicitly connected social justice to the concerns that she has about the stratification and marginalization that exists within society. At the time of this study, Lucy was teaching in a dual language (American Sign Language-spoken English), fifth-grade classroom composed of deaf and hard-of-hearing students, hearing students with deaf family members, and hearing students with no previous affiliation with the deaf community. Lucy's commitment to creating an inclusive and critically aware environment in her classroom is therefore closely related to the unique context in which she teaches. Troubled by social hierarchies and normative ideals, Lucy spoke with passion about fighting the repercussions of both racism and ableism in the lives of her students. She was motivated to address themes of rights, responsibility, and respect-key components of her conceptions of social justice - to prepare her students for the injustices they will face in their daily lives. Despite the pressures of accountability, Lucy, in collaboration with her deaf coteacher, argued that issues of discrimination are too pressing in the lives of their students to ignore.

Lucy drew heavily on her personal experiences as a Black Haitian woman when explaining her conceptions of social justice. When describing the in-depth social justice-related discussions she has with her students, she indicated,

I ask them if they have had any experiences not being treated fairly, and I tell them my own experiences. Everything I do, I try to relate it back to something that has happened to me or something I went through.

In addition, she shared how the low expectations communicated to her as a young Black child have pushed her to hold high academic expectations for her deaf students. Developing strength and resiliency against social marginalization, as well as the capacity to advocate for the rights of others, are subjects so important to Lucy that she sometimes forgoes mandated curricula to address them when they emerge in the classroom. With respect to those classrooms that do not center stories of discrimination, she speculated that they were led by teachers who had been protected and privileged in their lives: "They haven't been through it. We talk about it a lot because we've both been through it." Clearly, Lucy addressed memories from her past in conceptualizing what it means to foster students' critical consciousness.

Lucy also praised her teacher education program for fostering honest and emotional class discussions through autobiographical self-reflection. She candidly described the moment in which she first spoke out in class about the pervasiveness of racism today, an emotional turning point in her studies that solidified her commitment to social justice and teaching. Lucy explained, "Until people realize what's going on, we can't come up with a solution. ... We're saying everything's all great now, and just last year somebody called me a nigger." Likewise, her student teaching experiences working with children from a gifted classroom forced her to interrogate her own prejudices around privilege and Whiteness, biases she admits she never recognized about herself. Lucy viewed teaching for social justice as a process through which discriminations reproduced by social stratification are urgently addressed.

Despite her personal beliefs about the importance of raising conversations about discriminatory social hierarchies, the translation of her conceptions into classroom curricula left her feeling ineffectual as a social justice teacher. Admitting that classroom discussions were "not enough" to curtail the travesties of discrimination, Lucy envisioned a longterm project wherein her deaf students would move toward greater activism. Struggling to describe what this social justice teaching could look like, she continued,

Like, something that . . . a lesson. . . . I don't know about one particular lesson . . . but like you know like, maybe a long-term project. . . . I want them to do rights for deaf people. And researching that and having some type of project and presenting it to people at the end.

Interestingly, the social justice lesson she chose as an observation was the type of long-term project she desired, although Lucy did not associate this example within her ideals of social justice teaching.

After missing the nationwide Penny Harvest deadline due to standardized test preparation, Lucy and her students developed their own fund-raising effort, titled The Robin Hood Project, with hopes of donating all proceeds to the local homeless shelter. Students spent months collecting pennies from other classrooms and writing letters to solicit donations from companies. Despite the potential strengths of this project, Lucy was occasionally unsure that she was enacting social justice curricula and, in reference to one of her lessons, asked, 
"Would that be social justice?" The Robin Hood Project may be seen as separate from her expressed conceptions of social justice as it did not address issues of racial and ableist marginalization. However, Lucy did admit to an increased sense of activism among her students due to The Robin Hood Project. She said, "This project has helped the students to gain confidence and has taught them important life skills that help them to navigate within a hearing world."

\section{Jane}

It's hard to find that balance between my own anxieties about how they're treating each other or how they're doing and how I can actually help them and stay true to a social justice-like mindset.

Jane grew up in Hawaii with a father who uneasily described himself as Chinese and a grandmother who would become the first Asian American teacher in her Michigan school district. In this context, Jane admitted to a sense of angst and inadequacy fostered by her grandmother's stories of racism and her experiences as a multiracial individual in American society. These feelings made her more sensitive to the needs of her racially diverse students. We met Jane when she worked in a school with students from a wide array of linguistically, culturally, economically, ethnically, and racially divergent backgrounds. However, despite the diversity, she explained that her students were "mostly kids of color, but kids who are not as wealthy as the others in the school." She communicated in her interview her concerns about "the ties of power to wealth" and "the link of race and privilege," and the diversity of her classroom gave her multiple opportunities to reflect on these dynamics among her students.

Jane's conceptions of teaching for social justice involved intentional efforts to undo unjust hierarchies of power. When Jane was asked how social justice related to her specific classroom, she expressed her attempt to "incorporate multiple perspectives" but followed up with, "Then, you go beyond that, like, how do you change power dynamics so that people who are always on top are sharing their power and everyone's kind of feeling like they can participate?" For Jane, a more equitable distribution of wealth could lead to this sharing of power. Her interest in "getting kids on the right track" both academically and behaviorally was tied to this social vision. If education is linked to opportunity, she rationalized, then what she does in the classroom to bolster academic skills may alleviate economic discrepancies on a wider societal basis.

Although Jane envisioned her students deliberating over social justice issues such as race and privilege, her preoccupation with a well-managed classroom at times inhibited her from actualizing this ideal. To this she declared, "If I can't have my community to run smoothly, if I can't have them treating each other appropriately, then how can I have them talking about some topic that's maybe going to be really controversial?" Jane saw respect and order as precursors to social justice--oriented dialogue, and she questioned her previous vision of "jumping in" and immediately provoking discussions about relevant and controversial topics. Jane was also focused on community building, as it was supported within her school. When asked how aspects of social justice may become folded into school life, she referred to the schoolwide 4Rs program launched by an organization named Educators for Social Responsibility. With a focus on conflict resolution, the 4Rs program institutes policies for students and teachers around anger management, advocacy, and community building. Jane did not think that the administrators of her school would be interested in teaching for social justice (as conceptualized by Jane) beyond these programs as they would not want teachers to introduce "radical changes or thoughts that might get into families."

Jane acknowledged that her teaching experiences prompted visceral shifts in her conceptions of what social justice teaching may actually mean. As she once believed teaching needed to directly raise conversations that pertain to marginalized groups in society, she admitted that social justice for her had now shifted toward "community and management" and "how to foster more appropriate treatment" among her students. These efforts were in line with visions of teaching for social justice forwarded by the administration and were in response to her experiences with her students.

Jane also recognized a disconnect between the messages of her teacher education program around teaching for social justice and her practice. She commented that although she graduated from her teacher education program no more than 9 months prior to the interview, what she learned about teaching was most certainly different from actually teaching in the classroom. As she reflected on her years in the program, she critiqued its theory-heavy orientation, commenting that even as students developed a social studies curriculum, she failed to see its practical value, stating, "It was still just theory for me."

Despite these perceived disconnects, when Jane invited us to observe a lesson addressing anti-immigration sentiment in Texas, it seemed apparent that both her initial and her emergent conceptions were present in her teaching style. Using a method she called Stand Up, she asked students to stand if they associated themselves with the various groups she named. These groupings ranged from eldest children to racial affiliation. Then she read an article to her students about immigration and fostered a discussion about the experiences of immigrants in America as highlighted by the author. Her efforts to teach respect for marginalized experiences and multiple perspectives were corroborated in a statement she recalled making to her students about historical accuracy. She recollected, "In class we talked about how we need to hear other voices speaking, so then, in history, we need to hear other voices too." 


\section{Allison}

Before you have a classroom, you think about how you want your classroom to be democratic and you want . . . everybody to have a place in it, and to feel safe, and to feel like they can really talk about what they're thinking about.

During the time of this study, Allison was a fifth-grade teacher and self-proclaimed "classroom manager." Working in a racially diverse classroom in a community she described as "very liberal, very artsy, with very artsy, open kind of parents," Allison was drawn to ideals that highlight fairness, inclusion, voice, and participation. Moved by readings from her teacher education program, particularly those that examined language use and student silencing, Allison admitted to an overly cautious desire to develop safe learning spaces where multiple perspectives and diversity were valued. Describing herself growing up, Allison explained that even as a White, middle-class girl from the suburbs, she always felt as if she did not belong. Calling this the root of her social justice conception, it may be clear to see how her childhood experiences burgeoned into a need to create safe classroom spaces.

Allison struggled to determine how she could develop a safe space - which she believed was a key marker of social justice education - while raising important topics of social concern. On one hand, she seemed committed to promoting open conversations despite the potential for conflict, stating, "Isn't it okay for a kid to have some strong opinion about another race, or something that I personally would get really upset to hear?" On the other hand, this conflict and discord deterred her from structuring such dialogue. When speaking about controversy in the classroom, she remarked, "What do you say? What do you not say?" and continued to explain her confusion as to how to address issues of class, race, and the achievement gap.

In addition, although Allison wanted her students to believe in a democracy where all voices are heard, she questioned how this could be done in an elementary school classroom. She said, "I don't think a classroom can be a complete democracy because you - as the experienced adult, educator, teacher, person responsible - need to be a figurehead, so then the question is, How much power do you design to give them?" In her attempts to elicit divergent thinking among her students, her concern for teacher voice and authority at times silenced her from openly sharing her opinions. Allison's apprehension around teacher power and control surfaced throughout her interview. At one point she noted, "I impose certain values on my class; I'm confident that those are values that I want to impose," then four turns of talk later, she said, "There's still that question of how much do you really impose or not. If you really want your students to be thinking for themselves then do you really need to tell them what you should think?" Allison recalled that the professors in her teacher education program modeled a value-laden curriculum through which they aired their opinions. She seemed appreciative that they displayed ways in which authority figures can openly express their ideals. However, she continued to worry about how this may contradict tenets of participation and open-mindedness.

Other school-oriented factors posed obstacles to Allison as she sought to create a safe learning space for her students. First, Allison described the mandated curriculum required by her school as a very real detriment to exploring content around social justice issues. She proclaimed, "You really do have to follow the standards and what unit you're supposed to be on." Second, she explained that the lack of supplemental resources had become even more problematic. For example, as Allison attempted to teach Westward expansion through multiple perspectives, she struggled to locate materials that spoke to the positionalities of more marginalized groups such as Mexicans, Asians, and women.

Maneuvering around school mandates, Allison adhered to administrative demands while working to foster safe, open dialogue with her students. When she invited us into her classroom, there was a notable fervor and energy in the air. The students were working in small groups, discussing how their lives would have been affected if they had lived during the time of the civil war. This fit her image of a lesson for social justice. She explained, "The kids' voices should be in there. There should be conversation back and forth. It's not the kind of lesson where I feel the teacher would be giving a lecture or something." When discussions became heated during her lesson about the civil war, she insisted that her students move past their own opinions and build off each other rather than refuse to listen.

As is evident in each of the cases described above, beginning teachers demonstrate an impressive ability to reflect on their practices, to measure conceptions of social justice against the realities of classroom teaching, and to name their struggles. In the next section, we reflect on the beginning teachers' stories and elucidate common themes from which implications may be drawn.

\section{Reading Across the Cases}

In studying the teachers' reflections on their work to teach for social justice, we are able to explore the beginning teachers' conceptions of teaching for social justice along with their perceptions of their practices. Their conceptions revealed that the teachers were motivated by ideals of open, deliberative dialogue and a realignment of problematic social hierarchies. Their practices, as observed in their classrooms, often reflected aspects of their visions. Yet the teachers all articulated different disconnections they felt between their ideals and their practices. This suggests that beginning teachers enter a 
complex enterprise wrought with tensions, conflicts, and contradictions when they aim to translate their conceptions into viable pedagogy. Many of the hindrances they described are attributable to the complexity of everyday teaching, which is intensified for beginning teachers, yet they reflect the even greater ambiguity around teaching for social justice. Given this, we celebrate the teachers' efforts to embrace and grapple with the conflicts at work in their practices, all while enacting curricula that displayed markers of teaching for social justice. We question how and if they may have joined in our celebration, as they seemed more likely to frame their efforts as incomplete. In this section, we first review Lucy's, Jane's, and Allison's experiences, highlighting their perceived struggles, and then review the overarching implications of their stories.

Lucy felt unsure about her ability to challenge systemic injustice through school curricula. Although she was faithful to her beliefs that institutional racism and ableism posed difficulties for her deaf students, Lucy felt that what she was doing in her classroom was just "not enough." Comparatively, we were struck by her sense of urgency and her willingness to push the core curriculum aside to make room for discussions about social inequity and injustice. These conversations show her commitment to redistribution of power in society, reflecting a social reconstructionist approach to curriculum (Sleeter, 1993). We also see reason to praise The Robin Hood Project in its expectation that students act as activists and advocate for the common good. Despite these strengths of her pedagogy, at this point in her teaching career, Lucy showed concern about her inability to be the teacher activist that she wanted to be, that she felt her students needed her to be, and that her preservice teacher education program promoted.

Jane's goals changed as she developed more teaching experience. She entered the classroom with a belief that social justice teaching should raise awareness of particular issues of injustice and foster dialogue that welcomed multiple perspectives. Concerned about classroom management, she deliberately placed an emphasis on community building and collaboration so as to make these kinds of conversations possible. She distanced her present pedagogy from her ideals and from those communicated in her teacher education program. However, despite her perceived disconnect, the Stand Up lesson reflected her dedication and possible success in teaching students to engage in rich dialogue about relevant topics as she enabled students to think about immigration from different points of view.

Allison's case raised issues of authority and voice in democratic classrooms. She articulated a commitment to ideals of sharing authority (Oyler, 1996) and promoting open dialogue, illustrating her dedication to student voice and relevant, yet potentially controversial, issues. Allison reflectively deliberated about the power dynamics present in her classroom and became concerned that she was imposing her own voice and "privileging" her opinions (Hess, 2005). Her thoughtfulness about these issues was notable and showed a sophisticated level of reflection. She did not praise herself in this way, however, and was bothered by the possibility that she might be alienating students and using her power in problematic ways. Overall, she admitted doubts about how her vision of shared authority and open dialogue could be applied to a classroom setting.

The teachers' reflections on their conceptions and practices show their desire to advocate for social change through classroom pedagogy, build cooperative classroom communities, and monitor their authority to allow for the expression of student voice. Clearly, they set standards for their ideal classrooms. We believe that teachers are theory builders who establish connections between their conceptions and practices (Schoonmaker \& Ryan, 1996). Our experiences with Lucy, Jane, and Allison illustrate their abilities to engage in this work. The beginning teachers analyzed their practices in reference to their conceptions of teaching for social justice. As their classroom practices reflected markers of their particular ideals, it is clear that all the teachers studied were engaged in a journey toward teaching for social justice.

Furthermore, as these educators raised questions about social justice pedagogy, their reflections suggest potential next steps for themselves in their practices. Lucy's next step involved enacting a curricular unit revolving around an essential question that highlights a form of systemic inequity. Jane wished to continue developing new strategies to help her students build community, listen, and ultimately advocate for each other. Allison may establish an open dialogue with her students on a controversial topic and experiment with different models of teacher disclosure to feel more security about what she can and cannot say in the classroom. The limitations that they identified in their teaching are illustrative of their forthcoming development as teachers.

Their analyses of their practices are particularly praiseworthy given the well-researched obstacles facing beginning teachers who are committed to social justice in today's schools. Most salient is the current context of standards and accountability in schools, where teachers face pressures of mandated curricula, inflexible daily schedules, and imposed test preparation. Moreover, beginning teachers are at a particularly challenging stage of their professional development. They are experimenting, possibly for the first time, with the tenuous connections between their conceptions and their practices, and as a result, there are unexpected challenges. In the face of these hindrances, Lucy, Jane, and Allison saw a place for socially transformative pedagogy. They took steps and identified how their practices could be improved. They were not willing to be derailed by the impact of imposed systems of curricular regulation or overly consumed by their status as beginning teachers.

However, the teachers did not always praise their struggles in this way. Conversely, they more often seemed to dismiss their important work as not good enough or potentially problematic. Rather than seeing their doubts as opening moments for learning or self-growth, they looked down on aspects of their 
teaching that were different from or did not yet reach their ideals. They did not necessarily see their questions as pushing them forward toward greater disruption of the status quo.

This distance between the strengths of Lucy's, Jane's, and Allison's pedagogy and their own perceptions of their teaching raises a number of questions for teacher educators. How can teachers be encouraged to see their work as constitutive of a larger ideal without dismissing it through an overly critical evaluation process? Do grand notions of social justice teaching and phrasing such as teaching to change the world force idealistic goals on teachers that thwart their efforts to reflect on and honor their lived experiences and their steps toward an ideal? To address these questions, teacher educators could work to help teachers identify the context-specific connections between their conceptions and their practice and to value their own commitments to social justice as they exist within any one classroom experience. Given the plurality of teacher experiences, student identities, and classroom dynamics, it should be expected that teachers teach for social justice differently at different moments in their careers. Teachers can value a social reconstructionist approach and work with the goals of systemic change in mind without uniformly fitting into any one model of teaching for social justice at all times. If Lucy, Jane, and Allison were comfortable with this idea, they may have been able to value their own contextspecific iterations of teaching for social justice and recognize the connections between their conceptions of teaching for social justice and their pedagogy.

We acknowledge that our participants' outlooks about social justice curricula and their perceptions of their own abilities as educators most likely changed significantly as they entered their 2 nd and 3rd years of teaching. Indeed, a teacher's 1st year of teaching is a time that is commonly identified as trying, if not painful. Focusing on this group points to a possible limitation of this research, as readers may ask how 1st-year teachers in particular could teach in accordance with their ideals. However, we chose to observe beginning teachers because we noted that there was a paucity of studies following up with recent graduates of teacher education programs and exploring the ways in which they have integrated social justice into their curricula. We felt that it was important to capture these crucial moments in their development as educators to pinpoint ways that preservice programs can support nascent teachers and encourage them to enact social justice curricula even in their first classrooms. Lucy's, Jane's, and Allison's stories illustrate the potentially powerful work of beginning teachers and can offer helpful feedback for teacher education programs.

\section{Recommendations}

As a research team and as a group of teacher educators committed to supporting curricula that emphasize social justice, we hope to support beginning teachers and teacher educators to create avenues for classrooms that challenge racist, sexist, classist, ableist, and heterosexist norms. We also seek to help beginning teachers understand that such goals are both feasible and realistic, even within the harrowing 1st years of teaching. To reinforce these goals, we argue that preservice teacher educators consider the following recommendations as we prepare beginning teachers.

Elucidate the inevitable struggles around teaching for social justice. Preservice graduates should be armed with the knowledge that their conceptions of justice-oriented teaching will change in accordance with their struggles around and reflections on their pedagogy, students, and school contexts. We suggest that teacher education programs carve out space for discussions that help teachers to see teaching for social justice as a journey, not a finished product. This will help beginning teachers understand or even deflect their frustrations when they face the hindrances that will get in the way of their visions. Teaching - it must be understood - is no different from any other human endeavor: Our efforts can be guided and sustained by our greater vision, but our daily behaviors often fall short of our lofty ambitions.

Often, preservice programs present remarkable, experienced teachers as the ideal to which their students should aspire and fail to explain that such teaching does not come easily and that nearly all new educators struggle during their 1 st years in the field. Instead, teacher education programs might present the stories of beginning teachers, such as those of Lucy, Jane, and Allison, to demonstrate both the possibilities and the challenges of enacting social justice curricula in the 1 st years of teaching. These programs might also invite a panel of recent graduates to speak candidly with students about both their trials and their successes. Preparing teachers to see teaching for social justice as an uncertain and tumultuous process may aid them to overcome, acknowledge, and cope with the myriad constraints they may face as they work to enact social justice curricula. Rather than be disappointed because they continue to struggle with their practices, we wish to cultivate an expectation for struggle and even an appetite for such struggle. Indeed, it is only through collective struggle that major social movements exercise their power and change the course of human events.

Scaffold opportunities for student teachers to practice reflectivethinking skills. This research confirms once again the importance of preparing teachers to be reflective about their practices. We see much hope in the beginning teachers' abilities to name and grapple with aspects of their own autobiographies and the questions facing them in their first classroom teaching positions. Yet although Lucy, Jane, and Allison demonstrated practices that reflected a social justice orientation and vision, all three had trouble recognizing this and instead expressed that their visions were presently incongruous with their practice. Thus, they were able to reflect on their practices, but they often did so in a disappointed way, criticizing their own efforts as falling short of their greater visions.

The teachers' tendency to critique led us to reconsider how we teach the process of reflection. As almost all teacher 
education programs require student teachers to keep a daily or weekly journal, we want to recommend that student teachers' reflections be scaffolded with an eye toward the specific consequences and outcomes for learners when teachers make pedagogical decisions. That is, rather than focusing on how the teacher's performance falls short of his or her vision, we would like teachers to be able to take careful stock of what the students learned and accomplished. We want teachers who can carefully assess the outcomes of their pedagogical decisions rather than rely on any external conceptions of correct social justice pedagogy that they may have picked up in their teacher education program. When teachers reflect in this way, they more often may be able to celebrate their successes and abilities to teach for social justice.

Explore resources in teacher education classrooms to plan social reconstructionist curricula enactments. Teacher educators should make space in their syllabi for texts, materials, and speakers that either detail a social justice curricular vision in action or can be used to create such plans. We are hopeful about the power of texts to offer specific images of social justice-oriented pedagogy from inside individual classrooms. We use books such as Black Ants and Buddhists (Cowhey, 2007) and Writing in Rhythm (Fisher, 2007) and those by the Rethinking Schools collective, all of which detail curricula that question injustice and scaffold opportunities for students to envision and advocate for a better world. Although many of the practices illustrated should be questioned and tailored to different classrooms, they can foster conversations about the possibilities and limitations of social justice curriculum enactments in schools today. These types of books can be used as examples for curriculum planning as a precursor to group curriculum planning starting with local artifacts and experiences. For instance, teacher educators can arrange field trips (to museums, cultural events, or the offices of a community-based organization) and then come back to campus and engage in writing instructional plans making the link between a variety of social justice-oriented goals and state learning standards. In this way, student teachers' social justiceoriented curricular planning can be coached and supported through peer interaction. Furthermore, teacher educators can demonstrate that the same materials and learning experiences can be used to reach a range of differing social justice goals, which ultimately may help student teachers consider the relationship between their own ideological orientations, the pedagogical choices they make, and the subsequent possible learning outcomes for children.

When teacher educators embrace these steps, their graduates may be prepared for the journeys they will face as they move with their social justice commitments into the world of public schooling. Each year, thousands of teachers depart from their preservice programs, certificates in hand, eager to use the skills that they have learned to effect change and interrupt the racial and social norms that have long plagued our school system and our society. During the course of this research study, we found that educators with fervent commitments to social reconstructionist education can question their abilities to teach in accordance with their values. Yet we also found that these new teachers are more than capable of enacting social justice curricula in significant ways. As teacher educators, we must take concrete steps to support our students' dedication to social justice and to preemptively prepare them for their self-doubts and help them celebrate their successes. Our own commitments to social justice should impel us to equip our preservice students with the curricular, theoretical, and psychological tools to pursue their justice-oriented ideals in their classrooms.

\section{Declaration of Conflicting Interests}

The author(s) declared no potential conflicts of interests with respect to the authorship and/or publication of this article.

\section{Financial Disclosure/Funding}

The author(s) received no financial support for the research and/or authorship of this article.

\section{References}

Adams, M., Bell, L., \& Griffin, P. (2006). Teaching for diversity and social justice: A sourcebook (2nd ed.). New York: Routledge.

Banks, C., \& Banks, J. (1995). Equity pedagogy: An essential component of multicultural education. Theory Into Practice, 43(3), 152-158.

Berlak, A., \& Moyenda, S. (2001). Taking it personally: Racism in the classroom from kindergarten to college. Philadelphia: Temple University Press.

Clandinin, D. J., \& Connelly, F. M. (2000). Narrative inquiry: Experience and story in qualitative research. San Francisco: Jossey-Bass.

Cochran-Smith, M. (2004). Walking the road: Race, diversity and social justice in teacher education. New York: Teachers College Press.

Cowhey, M. (2007). Black ants and Buddhists: Thinking critically and teaching differently in the primary grades. Portland, ME: Stenhouse.

Darling-Hammond, L., French, J., \& Garcia-Lopez, S. P. (2002). Learning to teach for social justice. New York: Teachers College Press.

Derman-Sparks, L., \& Ramsey, P. (2006). What if all the kids are White? Anti-bias, multicultural education with young children and families. New York: Teachers College Press.

Dyson, A., \& Genishi, C. (2005). On the case: Approaches to language and literacy research. New York: Teachers College Press.

Emerson, R. M., Fretz, R. I., \& Shaw, L. L. (1995). Writing ethnographic fieldnotes. Chicago: University of Chicago Press.

Feiman-Nemser, S. (2003). What new teachers need to learn. Educational Leadership, 60(8), 25-29.

Ferguson, A. A. (2000). Bad boys: Public schools in the making of Black masculinity. Ann Arbor: University of Michigan Press.

Fisher, M. (2007). Writing in rhythm: Spoken word poetry in urban classrooms. New York: Teachers College Press.

Genor, M., \& Goodwin, A. L. (2005). Confronting ourselves: Using autobiographical analysis in teacher education. New Educator, 1(4), 311-331. 
Glesne, C., \& Peshkin, A. (1992). Becoming qualitative researchers. White Plains, NY: Longman.

Hale, S. (1991). Feminist method, process, and self-criticism: Interviewing Sudanese women. In S. Gluck \& D. Patai (Eds.), Women's words: The feminist practice of oral history (pp. 121-136). London: Routledge.

Hatch, J. A. (1995). Ethical conflicts in classroom research: Examples from a study of peer stigmatization in kindergarten. In J. A. Hatch (Ed.), Qualitative research in early childhood settings (pp. 213-222). Westport, CT: Praeger.

Hehir, T. (2002). Eliminating ableism in education. Harvard Educational Review, 72(1), 1-32.

Hess, D. (2005). How do teachers' political views influence teaching about controversial issues? Social Education, 69(1), 47-48.

Holstein, J. A., \& Gubrium, J. F. (1995). The active interview. Thousand Oaks, CA: Sage.

Irvine, J. (2003). Educating teachers for diversity: Seeing with a cultural eye. New York: Teachers College Press.

Kluth, P., Straut, D., \& Biklen, D. (2003). Access to academics for all students: Critical approaches to inclusive curriculum, instruction, and policy. Mahwah, NJ: Lawrence Erlbaum.

Kozol, J. (1991). Savage inequalities. New York: Crown.

Kumashiro, K. (2004). Against common sense: Teaching and learning toward social justice. New York: RoutledgeFalmer.

Ladson-Billings, G. (1994). The dreamkeepers: Successful teachers of African American children. San Francisco: Jossey-Bass.

Lalas, J. (2007). Teaching for social justice in multicultural urban schools: Conceptualization and classroom implication. Multicultural Education, 14(3), 17-21.

Lather, P. (1986). Issues of validity in openly ideological research: Between a rock and a soft place. Interchange, 17(4), 63-84.

Linton, S. (1998). Claiming disability: Knowledge and identity. New York: New York University Press.

Losen, L., \& Orfield, G. (2002). Racial inequality in special education. Cambridge, MA: Harvard University Press.

McDonald, M. (2007). The joint enterprise of social justice teacher education. Teachers College Record, 109(8), 2047-2081.

Mukherjee, E. (2007). Criminalizing the classroom: The overpolicing of New York City schools. New York: New York Civil Liberties Union.

Nieto, S. (2005). Public education in the twentieth century and beyond: High hopes, broken promises, and an uncertain future. Harvard Educational Review, 75(1), 43-64.

Oakes, J., \& Lipton, M. (2007). Teaching to change the world (3rd ed.). New York: McGraw-Hill.

Oakes, J., Wells, A., Jones, M., \& Datnow, A. (1997). Detracking: The social construction of ability, cultural politics, and resistance to reform. Teachers College Record, 98, 482-510.

Oyler, C. (1996). Making room for students: Sharing teacher authority in room 104. New York: Teachers College Press.

Ramsey, P. (2004). Teaching and learning in a diverse world (3rd ed.). New York: Teachers College Press.

Rothstein, R. (2004). Class and schools: Using social, economic, and educational reform to close the Black-White achievement gap. Washington, DC: Economic Policy Institute.
Sapon-Shevin, M. (1999). Because we can change the world: A practical guide to building cooperative, inclusive, classroom communities. Needham Heights, MA: Allyn \& Bacon.

Schniedewind, N., \& Davidson, E. (2006). Open minds to equality: A sourcebook of activities to affirm diversity and promote equity (3rd ed.). Milwaukee, WI: Rethinking Schools.

Schoonmaker, F., \& Ryan, S. (1996). Does theory lead practice? Teachers' constructs about teaching: Top down perspectives. Advances in Early Education and Day Care, 8, 117-151.

Sleeter, C. (1993). Multicultural education: Five views. Education Digest, 58(7), 53-57.

Sleeter, C. (2005). Un-standardizing curriculum: Multicultural teaching in the standards-based classroom. New York: Teachers College Press.

Snyder, J., Bolin, F., \& Zumwalt, K. (1992). Curriculum implementation. In P. W. Jackson (Ed.), Handbook of research on curriculum (pp. 402-435). New York: Macmillan.

Soohoo, S. (2006). Falling leaves: Narratives of otherness. Cresskill, NJ: Hampton Press.

Wade, R. (2007). Social studies for social justice: Teaching strategies for the elementary classroom. New York: Teachers College Press.

Zollers, N., Albert, L., \& Cochran-Smith, M. (2000). In pursuit of social justice: Collaborative research and practice in teacher education. Action in Teacher Education, 22(2), 1-14.

\section{About the Authors}

Rachel Oppenheim is a doctoral candidate in the Department of Curriculum \& Teaching at Teachers College, Columbia University. Her current research focuses on the educational lives of incarcerated women. Other areas of interests include disability studies, inclusive education, and feminist poststructuralism.

Ruchi Agarwal is an assistant researcher and lecturer at the University of California, Santa Cruz, in the Department of Education. Her research interests include issues related to social justice, teacher education, and curriculum design.

Shira Epstein is an assistant professor at the City College of New York in the Department of Secondary Education. Her research agenda focuses on citizenship education and what happens when adolescents and teachers work together to advocate for social change during the school day.

Celia Oyler is an associate professor in the Department of Curriculum \& Teaching at Teachers College, Columbia University. Her work focuses on supporting teachers, researchers, and activists engaged in inclusive education; critical multicultural education; and social action projects.

Debbie Sonu is an assistant professor in the Department of Curriculum and Teaching at Hunter College (City College of New York). Her research interests include justice and ethics in urban schools, poststructural thought, and critical theory. She is currently working on a piece about friendship and ethical decision making in the classroom and has recently published on institutionalizing activism in public schools. 